\title{
One-Step Synthesis of $\left[\mathrm{HM}_{3}(\mathrm{CO})_{11}\right]^{-}$from $\mathrm{M}_{3}(\mathrm{CO})_{12}(\mathrm{M}=$ $\mathrm{Fe}, \mathrm{Ru}, \mathrm{Os}$ ) via Unusual Hydride Transfer from 1,3,5-Trimethyl-1,3,5-triazacyclohexane
}

\author{
Yu-Chiao Liu and Wen-Yann Yeh* \\ Department of Chemistry, National Sun Yat-Sen University, Kaohsiung, Taiwan 804 \\ Gene-Hsiang Lee and Shie-Ming Peng \\ Department of Chemistry, National Taiwan University, Taipei, Taiwan 106
}

Received J uly 9, 2003

\begin{abstract}
Summary: Reactions of $\mathrm{M}_{3}(\mathrm{CO})_{12}$ and $\left(\mathrm{MeNCH}_{2}\right)_{3}(1,3,5-$ trimethyl-1,3,5-triazacycl ohexane) in refluxing n-hexane generate the anionic hydrido clusters $\left[(\mu-\mathrm{H}) \mathrm{M}_{3}(\mathrm{CO})_{11}\right]-$ [MeN $\left(\mathrm{MeNCH}_{2}\right)_{2} \mathrm{CH}$ ] (1 and $\mathbf{2}$ for $\mathrm{M}=\mathrm{Fe}$ and $\mathrm{Ru}$, respectively) in good yields, while heating $\mathrm{Os}_{3}(\mathrm{CO})_{12}$ and $\left(\mathrm{MeNCH}_{2}\right)_{3}$ results in fragmentation of the triazacyclohexane ligand to yield the amidino complex $(\mu-\mathrm{H}) \mathrm{Os}_{3}-$ $(\mathrm{CO})_{9}\left(\mu_{3}, \eta^{2}-\mathrm{CH}(\mathrm{NMe})_{2}\right)(4)$. The $\mathrm{Os}_{3}$ anal ogue $\left[(\mu-\mathrm{H}) \mathrm{Os}_{3}-\right.$ $\left.(\mathrm{CO})_{11}\right]\left[\mathrm{MeN}\left(\mathrm{MeNCH}_{2}\right)_{2} \mathrm{CH}\right]$ (3) is produced by treatment of $\mathrm{Os}_{3}(\mathrm{CO})_{12}$ with $\left(\mathrm{MeNCH}_{2}\right)_{3}$ in the presence of $\mathrm{Me}_{3} \mathrm{NO}$ at room temperature or by treatment of $\mathrm{Os}_{3}(\mathrm{CO})_{11}(\mathrm{NCMe})$ with $\left(\mathrm{MeNCH}_{2}\right)_{3}$ at room temperature. A pathway involving $\beta$-hydride abstraction from a $\mathrm{CH}_{2}$ unit of the bound $\left(\mathrm{MeNCH}_{2}\right)_{3}$ ligand is proposed. The molecular structures of $\mathbf{2}$ and $\mathbf{4}$ are determined by an X-ray diffraction study.
\end{abstract}

\section{Introduction}

The trinuclear cluster anions $\left[(\mu-\mathrm{H}) \mathrm{M}_{3}(\mathrm{CO})_{11}\right]^{-}$of iron group metals $\left(\mathrm{M}=\mathrm{Fe}^{1}{ }^{1} \mathrm{Ru}^{2}{ }^{2} \mathrm{Os}^{3}\right)$ are important starting compounds for the preparation of a variety of cluster derivatives. ${ }^{4}$ In addition, interest has been stimulated by the potential for these compounds to serve as a homogeneous catalyst in hydroformylation, ${ }^{5}$ hydrogenation, ${ }^{6}$ water-gas shift reactions, ${ }^{7}$ etc. There are several

(1) (a) Case, J . R.; Whiting, M. C. J . Chem. Soc. 1960, 4632. (b) Dahl, L. F.; Blount, J . F. I norg. Chem. 1965, 4, 1373. (c) Forster, A.; J ohnson, B. F. G.; Lewis, J .; Matheson, T. W.; Robinson, B. H.; J ackson, W. G. J. Chem. Soc., Chem. Commun. 1974, 1043.

(2) (a) Knight, J .; Mays, M. J . J . Chem. Soc., Dalton Trans. 1972, 1022. (b) J ohnson, B. F. G.; Lewis, J .; Orpen, A. G.; Raithby, P. R.; Süss, G. J . Organomet. Chem. 1979, 173, 187.

(3) (a) Gavens, P. D.; Mays, M. J . J . Organomet. Chem. 1978, 162, 389. (b) Eady, C. R.; Guy, J .J .; J ohnson, B. F. G.; Lewis, J .; Malatesta, M. C.; Sheldrick, G. M. J . Chem. Soc., Chem. Commun. 1976, 602.

(4) (a) Shriver, D. F.; Kaesz, H. D.; Adams, R. D. The Chemistry of Metal Cluster Complexes; VCH: New York, 1990. (b) Akita, M. In Comprehensive Organometallic Chemistry II; Pergamon: Oxford, U.K., 1995; Vol. 7, p 259. (c) Deeming, A. J . In Comprehensive Organometallic Chemistry II; Pergamon: Oxford, U.K., 1995; Vol. 7, p 683.

(5) (a) Süss-Fink, G. J . Organomet. Chem. 1980, 193, C20. (b) SüssFink, G.; Meister, G. Adv. Organomet. Chem. 1993, 35, 41.

(6) (a) Bradley, J . S. J . Am. Chem. Soc. 1979, 101, 7419. (b) SüssFink, G.; Reiner, J . J . Mol. Catal. 1982, 16, 231.

(7) (a) Ford, P. C. Acc. Chem. Res. 1981, 14, 31. (b) Catalysis by Diand Polynuclear Metal Cluster Compounds; Adams, R. D., Cotton, F. A., Eds.; Wiley-VCH: New York, 1998. literature reports on the syntheses of $\left[(u-\mathrm{H}) \mathrm{M}_{3}(\mathrm{CO})_{11}\right]^{-}$, all of which involve reactions of $\mathrm{M}_{3}(\mathrm{CO})_{12}$ (and $\left.\mathrm{Fe}(\mathrm{CO})_{5}\right)$ with basic reagents, such as a triethylamine/water mixture in $\mathrm{THF}^{8}{ }^{8} \mathrm{NaBH}_{4}$ or $\mathrm{KH}$ in dry THF, ${ }^{9}$ and $\mathrm{KOH}$ in alcohol solvents. ${ }^{10}$ Usually, subsequent metathesis of small metal countercations by $\left[\mathrm{Et}_{4} \mathrm{~N}\right]^{+}$or $[\mathrm{PPN}]^{+}$ species is necessary to obtain stable salts.

The six-membered 1,3,5-trimethyl-1,3,5-triazacyclohexane molecule $\left(\left(\mathrm{MeNCH}_{2}\right)_{3}\right)$ is an attractive ligand for $\eta^{3}$-metal complexation. ${ }^{11} \mathrm{~F}$ or instance, thermolysis of $\mathrm{M}(\mathrm{CO})_{6}$ and $\left(\mathrm{MeNCH}_{2}\right)_{3}$ produces $\mathrm{M}(\mathrm{CO})_{3}\left(\eta^{3}-\left(\mathrm{MeNCH}_{2}\right)_{3}\right)$ $(\mathrm{M}=\mathrm{Cr}, \mathrm{Mo}, \mathrm{W})$ in good yields. ${ }^{12}$ In the present research, we expl ored the reactions of $\left(\mathrm{MeNCH}_{2}\right)_{3}$ with the iron group clusters $\mathrm{M}_{3}(\mathrm{CO})_{12}$, which lead to formation of $\left[(\mu-\mathrm{H}) \mathrm{M}_{3}(\mathrm{CO})_{11}\right]\left[\mathrm{MeN}\left(\mathrm{MeNCH}_{2}\right)_{2} \mathrm{CH}\right]$ quite unusually.

\section{Results and Discussion}

Reaction of $\mathrm{Fe}_{3}(\mathrm{CO})_{12}$ and $\left(\mathrm{MeNCH}_{2}\right)_{3}$ in refluxing n-hexane for $30 \mathrm{~min}$ affords a red precipitate, which is recrystallized from acetone/n-hexane to give a crystalline solid of $\left[(\mu-\mathrm{H}) \mathrm{Fe}_{3}(\mathrm{CO})_{11}\right]\left[\mathrm{MeN}\left(\mathrm{MeNCH}_{2}\right)_{2} \mathrm{CH}\right](\mathbf{1})$ in $80 \%$ yield (eq 1 ). Treatment of $\mathrm{Fe}_{2}(\mathrm{CO})_{9}$ with $\left(\mathrm{MeNCH}_{2}\right)_{3}$ at room temperature al so leads to 1 in $49 \%$ yiel d on the basis of the $\mathrm{Fe}$ atoms consumed. The ruthenium analogue $\left[(\mu-\mathrm{H}) \mathrm{Ru}_{3}(\mathrm{CO})_{11}\right]\left[\mathrm{MeN}\left(\mathrm{MeNCH}_{2}\right)_{2} \mathrm{CH}\right](2)$ is prepared similarly in $93 \%$ yield by heating $\mathrm{Ru}_{3}(\mathrm{CO})_{12}$ and $\left(\mathrm{MeNCH}_{2}\right)_{3}$ in n-hexane for $1 \mathrm{~h}$. On the contrary, no reactions occur between $\mathrm{Os}_{3}(\mathrm{CO})_{12}$ and $\left(\mathrm{MeNCH}_{2}\right)_{3}$ in refluxing $n$-hexane. At refluxing toluene temperature, however, fragmentation of the triazacyclohexaneligand

(8) (a) McFarlane, W.; Wilkinson, G. Inorg. Synth. 1966, 8, 181. (b) Keister, J . B.; Shapley, J . R.; Strickland, D. A. I norg. Synth. 1990, 27, 196. (c) Keister, J . B. J . Chem. Soc., Chem. Commun. 1979, 214.

(9) (a) Süss-Fink, G. I norg. Synth. 1986, 24, 168. (b) Bricker, J . C.; Nagel, C. C.; Shore, S. G. J . Am. Chem. Soc. 1982, 104, 1444.

(10) (a) Chen, C. K.; Cheng, C. H. Inorg. Chem. 1983, 22, 3378. (b) Burgess, K.; White, R. P. Inorg. Synth. 1990, 28, 236.

(11) Chantson, T. E.; Hancock, R. D. Inorg. Chim. Acta 1995, 230, 165.

(12) (a) Armanasco, N. L.; Baker, M. V.; North, M. R.; Skelton, B. W.; White, A. H. J. Chem. Soc., Dalton Trans. 1997, 1363. (b) Armanasco, N. L.; Baker, M. V.; North, M. R.; Skelton, B. W.; White, A. H. J . Chem. Soc., Dalton Trans. 1998, 1145. 


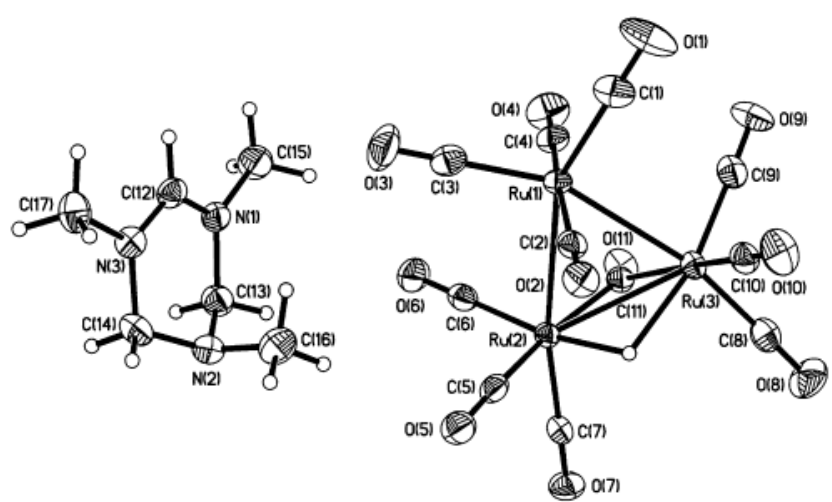

Figure 1. Molecular structure of 2. Selected bond distances $(\AA): \operatorname{Ru}(1)-R u(2)=2.8368(4), R u(1)-R u(3)=$ 2.8450(5), $\mathrm{Ru}(2)-\mathrm{Ru}(3)=2.8144(4), \mathrm{Ru}(2)-\mathrm{C}(11)=$ 2.084(4), $\mathrm{Ru}(3)-\mathrm{C}(11)=2.085(4), \mathrm{C}(11)-\mathrm{O}(11)=1.178-$ (5), $\mathrm{C}(12)-\mathrm{N}(3)=1.312(5), \mathrm{C}(12)-\mathrm{N}(1)=1.308(6), \mathrm{C}(14)-$ $\mathrm{N}(3)=1.473(5), \mathrm{C}(13)-\mathrm{N}(1)=1.476(6), \mathrm{C}(14)-\mathrm{N}(2)=$ $1.430(6), C(13)-N(2)=1.442(6)$. Selected bond angles (deg): $\mathrm{Ru}(1)-\mathrm{Ru}(2)-\mathrm{Ru}(3)=60.45(1), \mathrm{Ru}(1)-\mathrm{Ru}(3)-$ $\mathrm{Ru}(2)=60.16(1), \mathrm{Ru}(2)-\mathrm{Ru}(1)-\mathrm{Ru}(3)=59.38(1), \mathrm{Ru}(2)-$ $\mathrm{C}(11)-\mathrm{Ru}(3)=84.9(2), \mathrm{Ru}(2)-\mathrm{C}(11)-\mathrm{O}(11)=137.1(3)$, $\mathrm{Ru}(3)-\mathrm{C}(11)-\mathrm{O}(11)=137.9(3), \mathrm{N}(1)-\mathrm{C}(12)-\mathrm{N}(3)=$ $123.2(4), C(12)-N(1)-C(13)=118.8(4), C(12)-N(3)-C(14)$ $=119.6(4)$.

takes place to yield the ami dino complex $(u-\mathrm{H}) \mathrm{Os}_{3}(\mathrm{CO})_{9-}$ $\left(\mu_{3}, \eta^{2}-\mathrm{CH}(\mathrm{NMe})_{2}\right)(4)$ in $61 \%$ yield (eq 2 ) after separation by TLC. It is obvious that thermal dissociation of a carbonyl ligand from $\mathrm{M}_{3}(\mathrm{CO})_{12}$ is essential to initiating the reaction, and activation of the more robust Os-CO bond requires a higher temperature. ${ }^{13}$ Thus, the acetonitrile-substituted labile cluster $\mathrm{Os}_{3}(\mathrm{CO})_{11}(\mathrm{NCMe})$ reacts with $\left(\mathrm{MeNCH}_{2}\right)_{3}$ facilely at room temperature to produce $\left[(u-\mathrm{H}) \mathrm{Os}_{3}(\mathrm{CO})_{11}\right]\left[\mathrm{MeN}\left(\mathrm{MeNCH}_{2}\right)_{2} \mathrm{CH}\right]$ (3) in $61 \%$ yield (eq 3 ). An alternative method is by slow addition of $\mathrm{Me}_{3} \mathrm{NO}$ (to remove $\mathrm{CO}$ ) into a mixture of $\mathrm{Os}_{3}$ $(\mathrm{CO})_{12}$ and $\left(\mathrm{MeNCH}_{2}\right)_{3}$ at room temperature to afford $\mathbf{3}$ in $80 \%$ yield.

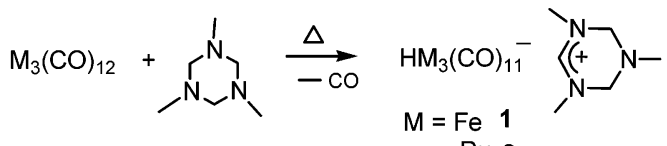

$$
\begin{aligned}
& \text { Ru } 2
\end{aligned}
$$

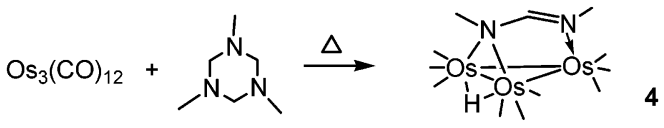

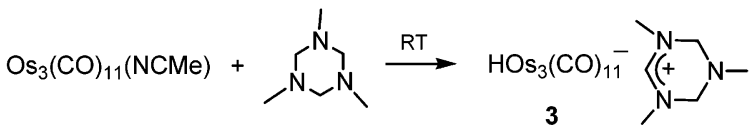

The molecular structure of 2, illustrated in Figure 1, was determined by an X-ray diffraction study to evidence the formation of the $\left[\mathrm{MeN}\left(\mathrm{MeNCH}_{2}\right)_{2} \mathrm{CH}\right]^{+}$countercation. The cluster part closely resembles that previously determined for $\left[(u-\mathrm{H}) \mathrm{Ru}_{3}(\mathrm{CO})_{11}\right][\mathrm{PPN}],{ }^{14}$ in which the dibridged $\mathrm{Ru}(2)-\mathrm{Ru}(3)$ distance is slightly but significantly shorter than the other intermetallic distances. The carbonyl $\mathrm{C}(11)-\mathrm{O}(11)$ bridges the $\mathrm{Ru}(2)-$

(13) Bonding Energies in Organometallic Compounds; Mark, T. J ., Ed.; American Chemical Society: Washington, 1990.

(14) J ohnson, B. F. G.; Lewis, J .; Raithby, P. R.; Süss, G. J . Chem. Soc., Dalton Trans. 1979, 1356.

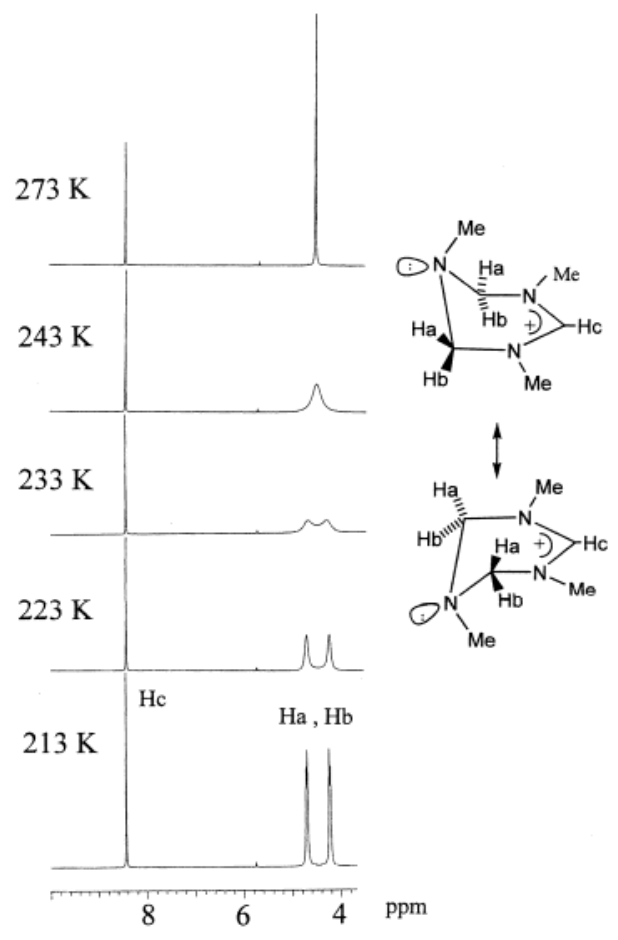

Figure 2. Variable-temperature $500 \mathrm{MHz}^{1} \mathrm{H}$ NMR spectra for 2 in $\left(\mathrm{CD}_{3}\right)_{2} \mathrm{CO}$. Only the $\mathrm{CH}$ and $\mathrm{CH}_{2}$ resonances of the $\left[\mathrm{MeN}\left(\mathrm{MeNCH}_{2}\right)_{2} \mathrm{CH}\right]^{+}$cation are displayed for comparison. The other resonance peaks are basically unchanged.

$\mathrm{Ru}(3)$ edge symmetrically, and the dihedral angle between the $\mathrm{Ru}(2)-\mathrm{C}(11)-\mathrm{Ru}(3)$ plane and the triruthenium plane is $102.04^{\circ}$. The $\left[\mathrm{MeN}\left(\mathrm{MeNCH}_{2}\right)_{2}-\right.$ $\mathrm{CH}]^{+}$cation contains a planar amidinium segment $(\mathrm{MeN})_{2} \mathrm{CH}^{+} .15$ The $\mathrm{N}(1)-\mathrm{C}(12)$ and $\mathrm{N}(3)-\mathrm{C}(12)$ bond distances are $1.308(6)$ and $1.312(5) \AA$, respectively, which are ca. $0.1 \AA$ shorter than the remaining $\mathrm{N}-\mathrm{C}$ bond lengths, ranging from $1.430(6)$ to $1.476(6) \AA$. In addition, the $\mathrm{C}-\mathrm{N}-\mathrm{C}$ angles surrounding the $\mathrm{N}(1)$ and $\mathrm{N}(2)$ atoms are close to $120^{\circ}$, indicating a delocalized double bond over the $\mathrm{N}(1)-\mathrm{C}(12)-\mathrm{N}(3)$ backbone.

Compounds 1-3 form deep red crystals, which are only slightly air-sensitive, but they become much more sensitive to oxygen in solution. They dissolve in common polar solvents. Their ${ }^{1} \mathrm{H}$ and ${ }^{13} \mathrm{C}$ NMR data, as well as the IR spectra in the carbonyl region for the cluster part $\left[(\mu-\mathrm{H}) \mathrm{M}_{3}(\mathrm{CO})_{11}\right]^{-}$, are in close agreement with those recorded in the literature. ${ }^{1-3}$ The cation $[\mathrm{MeN}$ (MeN$\left.\left.\mathrm{CH}_{2}\right)_{2} \mathrm{CH}\right]^{+}$is fluxional in solution. For example, the ${ }^{1} \mathrm{H}$ NMR spectrum of $\mathbf{2}$ at $-60^{\circ} \mathrm{C}$ shows a $1 \mathrm{H}$ singlet at $\delta$ 8.44 for the cationic $\mathrm{C}-\mathrm{H}$ resonance, two $2 \mathrm{H}$ doublets $(\mathrm{J}=12 \mathrm{~Hz})$ at $\delta 4.67$ and 4.22 for the $\mathrm{CH}_{2}$ resonances, a $6 \mathrm{H}$ singl et at $\delta 3.25$ and a $3 \mathrm{H}$ singlet at $\delta 2.57$ for the $\mathrm{CH}_{3}$ resonances, and a $1 \mathrm{H}$ singlet at $\delta-12.75$ for the $\mu-\mathrm{H}$ resonance. The $\mathrm{CH}_{2}$ signals collapse at $-40^{\circ} \mathrm{C}$ and merge as a singlet above $0{ }^{\circ} \mathrm{C}$ (Figure 2). From the coalescence point at ca. $243 \mathrm{~K}$, an approximate value of $\Delta \mathrm{G}^{\ddagger}=11 \mathrm{kcal} / \mathrm{mol}$ for the ring flipping can be estimated. ${ }^{16}$

Compound $\mathbf{4}$ forms an air-stable, yellow crystalline solid. The ${ }^{1} \mathrm{H}$ NMR spectrum shows a $1 \mathrm{H}$ singlet at $\delta$

(15) Willey, G. R.; Aris, D. R.; Aemaeg, W.; Errington, W. Inorg. Chim. Acta 2001, 317, 304.

(16) Drago, R. S. Physical Methods for Chemists, 2nd ed.; Saunders College Publishing: New York, 1992. 


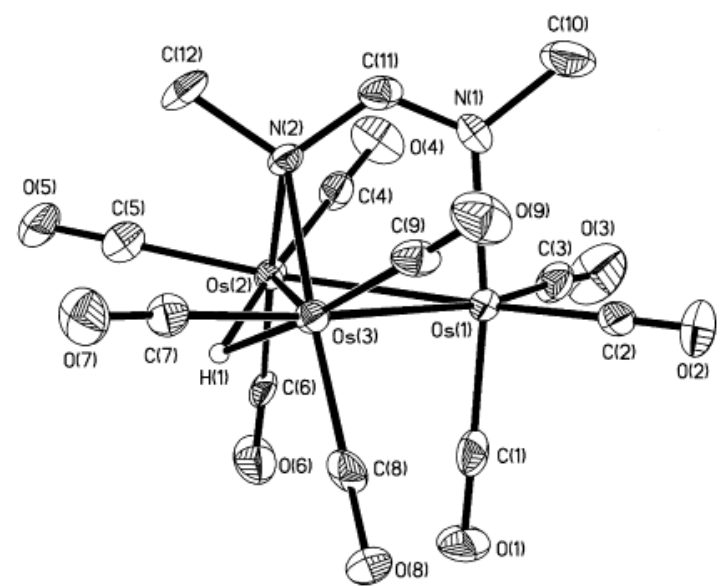

Figure 3. Molecular structure of 4. Selected bond distances $(\AA): \operatorname{Os}(1)-O s(2)=2.7899(5)$, Os $(1)-O s(3)=$ 2.7834(5), Os(2)-Os(3) = 2.7890(5), Os(1)-N(1) = $2.143(8), \operatorname{Os}(2)-\mathrm{N}(2)=2.179(7), \mathrm{Os}(3)-\mathrm{N}(2)=2.178(7)$, $\mathrm{C}(12)-\mathrm{N}(2)=1.49(1), \mathrm{C}(11)-\mathrm{N}(2)=1.40(1), \mathrm{C}(11)-\mathrm{N}(1)$ $=1.28(1), \mathrm{C}(10)-\mathrm{N}(1)=1.46(1)$. Selected bond angles (deg): Os(1)-Os(2)-Os(3) = 59.86(1), Os(1)-Os(3)-Os(2) $=60.09(1), \mathrm{Os}(2)-\mathrm{Os}(1)-\mathrm{Os}(3)=60.06(1), \mathrm{Os}(2)-\mathrm{N}(2)-$ $\mathrm{Os}(3)=79.62(2), \mathrm{C}(12)-\mathrm{N}(2)-\mathrm{C}(11)=110.4(7), \mathrm{N}(1)-$ $\mathrm{C}(11)-\mathrm{N}(2)=121.7(8), \mathrm{C}(11)-\mathrm{N}(1)-\mathrm{C}(10)=118.5(8)$.

\section{Scheme 1}

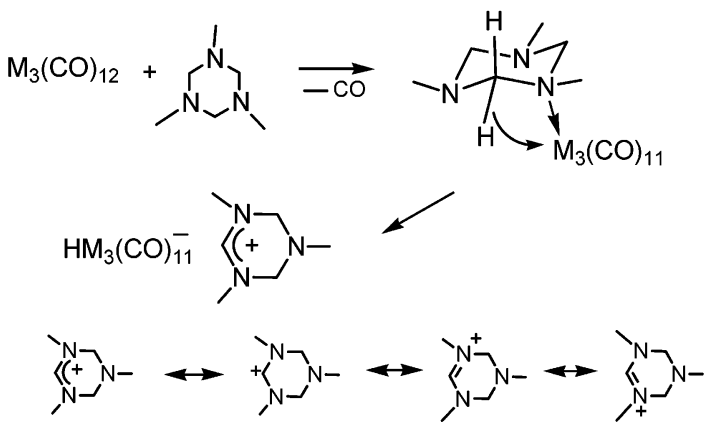

8.91, a $1 \mathrm{H}$ singlet at $\delta-11.04$, and two $3 \mathrm{H}$ singlets at $\delta 3.40$ and 3.24. Due to the absence of diagnostic spectral features to reveal the structure of $\mathbf{4}$, an X-ray diffraction study was conducted. There are two independent but structurally similar molecules in the asymmetric unit, and one of these is illustrated in Figure 3. The molecule consists of a triangular cluster of three $\mathrm{Os}(\mathrm{CO})_{3}$ units bridged by a hydrido and an amidino ligand on opposite sides of the $\mathrm{Os}_{3}$ triangl $\mathrm{e}^{17}$ The three Os-Os bond lengths are about equal, being $2.786 \pm$ $0.003 \AA$. E ach osmium atom is bonded to three terminal carbonyl groups with the $\mathrm{Os}-\mathrm{C}-\mathrm{O}$ angles ranging from $175.3(9)^{\circ}$ to $179.2(9)^{\circ}$. The ami dino group caps one $\mathrm{Os}_{3}$ face and formally donates five electrons to the cluster, where the $\mathrm{N}(2)$ atom may be considered to act as a three-electron donor symmetrically spanning the Os(2)-Os(3) edge, with the average Os-N(2) distance of $2.18 \AA$, and the $N(1)$ atom as a two-electron donor coordinated to the $\mathrm{Os}(1)$ atom with the distance of 2.143(8) $\AA$. The geometry about the $N(1)$ atom is essentially planar. The $\mathrm{C}(11)-\mathrm{N}(1)$ length of $1.28(1) \AA$ is characteristic of a $\mathrm{C}-\mathrm{N}$ double bond, which is $0.12 \AA$ shorter than the $\mathrm{C}(11)-\mathrm{N}(2)$ length of $1.40(1) \AA$.

A plausible reaction mechanism to account for the formation of 1-3 is depicted in Scheme 1. It formally involves $\eta^{1}$-coordination of triazacyclohexane substitut- ing for a $\mathrm{CO}$ (or NCMe) ligand, followed by $\beta$-hydride abstraction from a $\mathrm{CH}_{2}$ group to generate the anionic hydrido cluster. The latter process is likely driven by formation of a stable [MeN $\left.\left(\mathrm{MeNCH}_{2}\right)_{2} \mathrm{CH}\right]^{+}$cation with charge delocalization over the planar $\left(\mathrm{sp}^{2}\right) \mathrm{N}-\mathrm{C}-\mathrm{N}$ backbone. Since tetraazaadamantane is unable to form a planar $\left(\mathrm{CH}_{2} \mathrm{~N}\right)_{2} \mathrm{CH}^{+}$segment, it is not surprising that tetraazaadamantane shows no reactions with $\mathrm{Os}_{3}(\mathrm{CO})_{11^{-}}$ (NCMe) even at $80^{\circ} \mathrm{C}$ (eq 4).

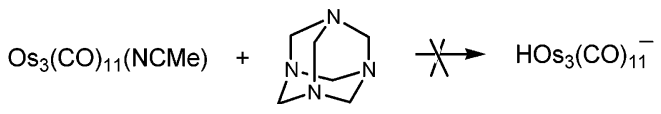

In conclusion, reaction of triazacycl ohexane with $\mathrm{M}_{3-}$ $(\mathrm{CO})_{12}$ of iron group metals represents a novel method for the synthesis of $\left[(\mu-\mathrm{H}) \mathrm{M}_{3}(\mathrm{CO})_{11}\right]^{-}$. It is simple and convenient, and the pure solid salt is readily obtained. We are currently investigating whether this synthetic method can be extended to other metal carbonyl systems.

\section{Experimental Section}

General Methods. All manipulations were carried out under an atmosphere of dinitrogen with standard Schlenk techniques. ${ }^{18}$ The metal carbonyls were purchased from Strem or Aldrich. $\mathrm{Os}_{3}(\mathrm{CO})_{11}(\mathrm{NCMe})$ was prepared by literature methods. ${ }^{19}$ 1,3,5-Trimethyl-1,3,5-triazacyclohexane $\left(\left(\mathrm{MeNCH}_{2}\right)_{3}\right)$ (from $\mathrm{TCl}$ ) was dried over $3 \AA$ molecular sieves before use. Anhydrous trimethylamine $\mathrm{N}$-oxide was obtained from $\mathrm{Me}_{3}-$ $\mathrm{NO} \cdot 2 \mathrm{H}_{2} \mathrm{O}\left(98 \%\right.$, Aldrich) by sublimation at $110{ }^{\circ} \mathrm{C}$ under vacuum. Solvents were dried over appropriate reagents under dinitrogen and distilled immediately before use. Preparative thin-layer chromatographic (TLC) plates were prepared from silica gel (Kieselegel, DGF 254 ). ${ }^{1} \mathrm{H}$ and ${ }^{13} \mathrm{C}$ NMR spectra were obtained on a Varian Unity IN OVA-500 spectrometer at 500 and $125.7 \mathrm{MHz}$, respectively. Fast-atom-bombardment (FAB) mass spectra were recorded on a Blotch-5022 mass spectrometer. Elemental analyses were performed at the National Science Council Regional Instrumentation Center at National Chen-Kung University, Tainan, Taiwan.

Thermal Reaction of $\mathrm{Fe}_{3}(\mathrm{CO})_{12}$ and $\left(\mathrm{MeNCH}_{2}\right)_{3}$. $\mathrm{Fe}_{3}$ $(\mathrm{CO})_{12}(100 \mathrm{mg}, 0.20 \mathrm{mmol}),\left(\mathrm{MeNCH}_{2}\right)_{3}(85 \mu \mathrm{L}, 0.60 \mathrm{mmol})$, and freshly distilled $\mathrm{n}$-hexane $(5 \mathrm{~mL})$ were placed in a Schlenk tube. The mixture was heated to reflux under dinitrogen for $30 \mathrm{~min}$, at which point a deep red precipitate was produced, and the IR spectrum of the solution showed no absorptions due to the starting cluster. After cooling to room temperature, the supernatant was removed by a syringe, and the solid washed with $\mathrm{n}$-hexane $(3 \times 1 \mathrm{~mL})$. The product was dried under vacuum and then recrystallized from acetone/n-hexane at room temperature, affording deep red crystals of $\left[(\mu-\mathrm{H}) \mathrm{Fe}_{3}-\right.$ $\left.(\mathrm{CO})_{11}\right]\left[\mathrm{MeN}\left(\mathrm{MeNCH}_{2}\right)_{2} \mathrm{CH}\right] \quad(\mathbf{1} ; 97 \mathrm{mg}, 80 \%)$. IR $\left(\mathrm{CH}_{2} \mathrm{Cl}_{2}\right.$, vCO): 2064 (vw), 1992 (vs), 1974 (s), 1900 (sh), 1694 (w) cm-1. ${ }^{1} \mathrm{H}$ NMR $\left(\mathrm{CD}_{3} \mathrm{COCD}_{3},-50{ }^{\circ} \mathrm{C}\right): \delta 8.44(\mathrm{~s}, 1 \mathrm{H}, \mathrm{CH}), 4.70(\mathrm{br}$, $\left.2 \mathrm{H}, \mathrm{CH}_{2}\right), 4.23\left(\mathrm{br}, 2 \mathrm{H}, \mathrm{CH}_{2}\right), 3.27(\mathrm{~s}, 6 \mathrm{H}, \mathrm{Me}), 2.61(\mathrm{~s}, 3 \mathrm{H}$, $\mathrm{Me}),-15.02(\mathrm{~s}, \mu-\mathrm{H}) .{ }^{13} \mathrm{C}\left\{{ }^{1} \mathrm{H}\right\} \mathrm{NMR}\left(\mathrm{CD}_{3} \mathrm{COCD}_{3}, 23{ }^{\circ} \mathrm{C}\right): \delta$ 229.3 (br, CO), $154.5(\mathrm{CH}), 67.6\left(\mathrm{NCH}_{3}\right), 40.0\left(\mathrm{CH}_{2}, \mathrm{NCH}_{3}\right)$.

An alternative method to prepare $\mathbf{l}$ is by stirring a suspension of $\mathrm{Fe}_{2}(\mathrm{CO})_{9}(100 \mathrm{mg}, 0.27 \mathrm{mmol})$ and $\left(\mathrm{MeNCH}_{2}\right)_{3}(114 \mu \mathrm{L}$, $0.81 \mathrm{mmol})$ in $\mathrm{n}$-hexane $(7 \mathrm{~mL})$ at room temperature for $3 \mathrm{~h}$

(17) An analogous complex $\mathrm{HO}_{3}(\mathrm{CO})_{9}(\mathrm{NPhC}(\mathrm{Ph}) \mathrm{NH})$ was prepared by the reaction of $\mathrm{Os}_{3}(\mathrm{CO})_{10}(\mathrm{NCMe})_{2}$ with amidine $(\mathrm{NHPhC}(\mathrm{Ph})=\mathrm{NH})$. Burgess, K.; Holden, H. D.; J ohnson, B. F. G.; Lewis, J . J . Chem. Soc., Dalton Trans. 1983, 1199.

(18) Shriver, D. F.; Drezdzon, M. A. The Manipulation of AirSensitive Compounds, 2nd ed.; Wiley: New York, 1986.

(19) Drake, S. R.; Khattar, R. Inorg. Synth. 1990, 28, 234. 
under dinitrogen. Compound $\mathbf{1}$ (54 mg, 49\% based on Fe atom) was obtained after recrystallization from acetone/n-hexane.

Thermal Reaction of $\mathrm{Ru}_{3}(\mathrm{CO})_{12}$ and $\left(\mathrm{MeNCH}_{2}\right)_{3} \cdot \mathrm{Ru}_{3}$ $(\mathrm{CO})_{12}(100 \mathrm{mg}, 0.16 \mathrm{mmol}),\left(\mathrm{MeNCH}_{2}\right)_{3}(60 \mu \mathrm{L}, 0.43 \mathrm{mmol})$, and freshly distilled $\mathrm{n}$-hexane $(5 \mathrm{~mL})$ were refluxed under dinitrogen for $1 \mathrm{~h}$, producing a deep red precipitate. The reaction was worked up in a fashion identical with that above. The product was recrystallized from $\mathrm{CH}_{2} \mathrm{Cl}_{2} / \mathrm{n}$-hexane at room temperature to afford deep red crystals of $\left[(\mu-\mathrm{H}) \mathrm{Ru}_{3}(\mathrm{CO})_{11}\right]-$ $\left[\mathrm{MeN}\left(\mathrm{MeNCH}_{2}\right)_{2} \mathrm{CH}\right] \quad(2 ; 110 \mathrm{mg}, 93 \%)$. Anal. Calcd for $\mathrm{C}_{17} \mathrm{H}_{15} \mathrm{~N}_{3} \mathrm{O}_{11} \mathrm{Ru}_{3}$ : C 27.57, $\mathrm{H}$ 2.04, N 5.67. Found: C 27.43, H 2.17, N 5.72. MS (FAB): m/z 587 [M- $-\mathrm{CO},{ }^{102} \mathrm{Ru}$ ]. IR (THF, vCO): 2072 (vw), 2004 (vs), 1984 (s), 1956 (m), 1710 (w), 1690 (w) $\mathrm{cm}^{-1} .{ }^{1} \mathrm{H} N M R\left(\mathrm{CD}_{3} \mathrm{COCD}_{3},-90^{\circ} \mathrm{C}\right): \delta 8.44(\mathrm{~s}, 1 \mathrm{H}, \mathrm{CH})$, $4.67\left(\mathrm{~d}, 2 \mathrm{H}\right.$, J $\left.=12 \mathrm{~Hz}, \mathrm{CH}_{2}\right), 4.22\left(\mathrm{~d}, 2 \mathrm{H}\right.$, J $\left.=12 \mathrm{~Hz}, \mathrm{CH}_{2}\right)$, $3.25(\mathrm{~s}, 6 \mathrm{H}, \mathrm{Me}), 2.57(\mathrm{~s}, 3 \mathrm{H}, \mathrm{Me}),-12.75(\mathrm{~s}, \mu-\mathrm{H}) .{ }^{13} \mathrm{C}\left\{{ }^{1} \mathrm{H}\right\}$ NMR $\left(\mathrm{CD}_{3} \mathrm{COCD}_{3},-90{ }^{\circ} \mathrm{C}\right): \delta 272.7(\mu-\mathrm{CO}), 210.2,209.3$, 203.1, 203.0, 197.4, $192.9(\mathrm{CO}), 153.3(\mathrm{CH}), 66.2\left(=\mathrm{N}-\mathrm{CH}_{3}\right)$, $39.6\left(\mathrm{CH}_{2}\right), 39.4\left(\mathrm{~N}-\mathrm{CH}_{3}\right)$.

Thermal Reaction of $\mathrm{Os}_{3}(\mathrm{CO})_{12}$ and $\left(\mathrm{MeNCH}_{2}\right)_{3} \cdot \mathrm{Os}_{3}-$ $(\mathrm{CO})_{12}(30 \mathrm{mg}, 0.03 \mathrm{mmol}),\left(\mathrm{MeNCH}_{2}\right)_{3}(14 \mu \mathrm{L}, 0.1 \mathrm{mmol})$, and toluene $(8 \mathrm{~mL})$ were introduced into a Schlenk flask, and the mixture was heated to reflux for $4 \mathrm{~h}$ under dinitrogen. The solution was cooled to room temperature, and the solvent removed under vacuum. The residue was separated by TLC with an n-hexane/dichloromethane (4:1) eluant. I solation of the material forming the third yellow-orange band afforded $(u-\mathrm{H}) \mathrm{Os}_{3}(\mathrm{CO})_{9}\left(u_{3}, \eta^{2}-\mathrm{CH}(\mathrm{NMe})_{2}\right)(\mathbf{4} ; 16 \mathrm{mg}, 61 \%)$. Anal. Calcd for $\mathrm{C}_{12} \mathrm{H}_{8} \mathrm{~N}_{2} \mathrm{O}_{9} \mathrm{OS}_{3}$ : C, 16.11; $\mathrm{H}, 0.90 ; \mathrm{N}, 3.13$. Found: C, 16.09; $\mathrm{H}, 0.97 ; \mathrm{N}, 3.09$. MS (FAB): $\mathrm{m} / \mathrm{z} 900$ (M+192Os). IR (hexane, $v \mathrm{CO}): 2084(\mathrm{~m}), 2052$ (s), 2020 (s), 1992 (s), 1978 (s), 1952 (m) $\mathrm{cm}^{-1} .{ }^{1} \mathrm{H} N M R\left(\mathrm{CDCl}_{3}, 25^{\circ} \mathrm{C}\right): \delta 8.91(\mathrm{~s}, 1 \mathrm{H}, \mathrm{CH}), 3.40(\mathrm{~s}$, $3 \mathrm{H}, \mathrm{Me}), 3.24(\mathrm{~s}, 3 \mathrm{H}, \mathrm{Me}),-11.04(\mathrm{~s}, \mu-\mathrm{H}) .{ }^{13} \mathrm{C}\left\{{ }^{1} \mathrm{H}\right\} \mathrm{NMR}$ $\left(\mathrm{CDCl}_{3}, 25^{\circ} \mathrm{C}\right): \delta 188.8,181.8,179.1,178.5,178.0(\mathrm{CO}), 181.0$ $(\mathrm{CH}), 64.4,51.4\left(\mathrm{CH}_{3}\right)$. The remaining minors bands were not characterized.

Reaction of $\mathrm{Os}_{3}(\mathrm{CO})_{11}(\mathrm{NCMe})$ and $\left(\mathrm{MeNCH}_{2}\right)_{3}$. $\mathrm{Os}_{3-}$ $(\mathrm{CO})_{11}(\mathrm{NCMe})(30 \mathrm{mg}, 0.033 \mathrm{mmol})$ was dissolved in $\mathrm{CH}_{2} \mathrm{Cl}_{2}$ $(5 \mathrm{~mL})$, and $\left(\mathrm{MeNCH}_{2}\right)_{3}(14 \mu \mathrm{L}, 0.1 \mathrm{mmol})$ was added. The mixture was stirred at room temperature for $30 \mathrm{~min}$ to yield a dark red solution, at which point the IR spectrum showed no absorptions due to the starting duster. The volatile materials were removed under vacuum, and the residue was washed with $\mathrm{n}$-hexane $(3 \times 1 \mathrm{~mL})$ under dinitrogen. The product was recrystallized from acetone/n-hexane in a freezer to afford red crystals of $\left[(u-\mathrm{H}) \mathrm{Os}_{3}(\mathrm{CO})_{11}\right]\left[\mathrm{MeN}\left(\mathrm{MeNCH}_{2}\right)_{2} \mathrm{CH}\right](3 ; 20 \mathrm{mg}$, 61\%). IR ( $\left.\mathrm{CH}_{2} \mathrm{Cl}_{2}, v \mathrm{CO}\right): 2040$ (w), 2016 (s), 1988 (s), 1952 (m), 1690 (w), 1676 (w) cm ${ }^{-1} .{ }^{1} \mathrm{H} N M R\left(\mathrm{CD}_{3} \mathrm{COCD}_{3}, 25^{\circ} \mathrm{C}\right): \delta 8.63$ $(\mathrm{s}, 1 \mathrm{H}), 4.46(\mathrm{~s}, 4 \mathrm{H}), 3.31(\mathrm{~s}, 6 \mathrm{H}), 2.66(\mathrm{~s}, 3 \mathrm{H}),-13.54(\mathrm{~s}, 1 \mathrm{H})$.

Reaction of $\mathrm{Os}_{3}(\mathrm{CO})_{12}$ and $\left(\mathrm{MeNCH}_{2}\right)_{3}$ in the Presence of $\mathrm{Me}_{3} \mathrm{NO} . \mathrm{Os}_{3}(\mathrm{CO})_{12}(30 \mathrm{mg}, 0.033 \mathrm{mmol}),\left(\mathrm{MeNCH}_{2}\right)_{3}(28 \mu \mathrm{L}$, $0.2 \mathrm{mmol})$, and $\mathrm{CH}_{2} \mathrm{Cl}_{2}(20 \mathrm{~mL})$ were placed in a Schlenk flask. A solution of $\mathrm{Me}_{3} \mathrm{NO}(2.7 \mathrm{mg}, 0.036 \mathrm{mmol})$ in $\mathrm{CH}_{2} \mathrm{Cl}_{2}(3 \mathrm{~mL})$ was slowly introduced into the flask over a period of $1 \mathrm{~h}$ at room temperature, resulting in a deep red solution. The volatile materials were removed under vacuum, and the residue was washed with $n$-hexane $(3 \times 1 \mathrm{~mL})$ under dinitrogen. The product was crystallized from acetone/n-hexane in a freezer to afford 3 (27 mg, 80\%).
Table 1. Crystallographic Data for 2 and 4

\begin{tabular}{|c|c|c|}
\hline & 2 & 4 \\
\hline $\begin{array}{l}\text { chem formula } \\
\text { cryst syst }\end{array}$ & $\begin{array}{l}\mathrm{C}_{17} \mathrm{H}_{15} \mathrm{~N}_{3} \mathrm{O}_{11} \mathrm{Ru}_{3} \\
\text { orthorhombic }\end{array}$ & $\begin{array}{l}\mathrm{C}_{12} \mathrm{H}_{8} \mathrm{~N}_{2} \mathrm{O}_{9} \mathrm{OS}_{3} \\
\text { triclinic }\end{array}$ \\
\hline fw & 740.53 & 894.80 \\
\hline space group & $\mathrm{P} 2_{1} 2_{1} 2_{1}$ & $\mathrm{P} \overline{1}$ \\
\hline$a, \AA$ & $11.8166(1)$ & $9.8983(3)$ \\
\hline$b, \AA$ & 11.9664(1) & $12.7390(4)$ \\
\hline$c, \AA$ & $17.0426(2)$ & $14.5342(5)$ \\
\hline$\alpha$, deg & 90 & $88.345(1)$ \\
\hline$\beta$, deg & 90 & $89.073(1)$ \\
\hline$\gamma$, deg & 90 & 89.957(1) \\
\hline$V, \AA^{3}$ & $2409.86(4)$ & 1831.7(1) \\
\hline Z & 4 & 4 \\
\hline $\bar{D}_{\text {calc }}, \mathrm{g} \mathrm{cm}^{-1}$ & 2.041 & 3.245 \\
\hline$\mu, \mathrm{mm}^{-1}$ & 1.916 & 20.806 \\
\hline $\mathrm{R}_{1} / \mathrm{R}_{\mathrm{w} 2^{\mathrm{a}}}$ & $0.0287 / 0.0664$ & $0.0399 / 0.0638$ \\
\hline GOF on $\mathrm{F}^{2}$ & 1.060 & 1.198 \\
\hline $\begin{array}{l}{ }^{a} R_{1}=\sum|| F_{0} \mid \\
\left.\left.v\left|F_{0}\right|^{4}\right\}\right\}^{1 / 2} .\end{array}$ & $d|/ \Sigma| F_{o} \mid \cdot R_{w 2}=$ & $\left.v\left(\left|F_{\mathrm{o}}\right|^{2}-\left|\mathrm{F}_{\mathrm{c}}\right|^{2}\right)^{2}\right] /$ \\
\hline
\end{tabular}

Structure Determination for $\mathbf{2}$ and $\mathbf{4}$. The crystals of $\mathbf{2}$ and $\mathbf{4}$ found suitable for $\mathrm{X}$-ray analysis were each mounted in a thin-walled glass capillary and aligned on the Nonius KappaCCD and Bruker Smart ApexCCD diffractometers, respectively, with graphite-monochromated Mo K $\alpha$ radiation $(\lambda=0.71073 \AA)$. The $\theta$ range for data collection is $2.08-27.50^{\circ}$ for 2 and $1.40-27.50^{\circ}$ for 4. Of the 20419 and 24381 reflections collected for $\mathbf{2}$ and $\mathbf{4}, 5513$ and 8403 reflections were independent, respectively. All data were corrected for Lorentz and polarization effects and for the effects of absorption. The structure was solved by the direct method and refined by leastsquares cycles. The non-hydrogen atoms were refined anisotropically. Hydrogen atoms were included but not refined. All calculations were performed using the SHELXTL-97 package. ${ }^{20}$ The data collection and refinement parameters are presented in Table 1 . The space group $\mathrm{P} 2_{1} 2_{1} 2_{1}$ for $\mathbf{2}$ is noncentrosymmetric; thus, in the course of the final structure factor calculation the program calculates the $\mathrm{Flack}^{21}$ absolute structure factor $x$ and its esd. A comparison of $x$ with its esd provides an indication as to whether the refined absolute structure is correct or whether it has to be "inverted". The true value of $\mathrm{x}$ is close to zero.

Acknowledgment. We are grateful for support of this work by the National Science Council of Taiwan.

Supporting Information Available: Complete tables of crystallographic data, positional parameters, anisotropic thermal parameters, bond angles, and bond distances of $\mathbf{2}$ and $\mathbf{4}$. This material is available free of charge via the Internet at http://pubs.acs.org.

\section{OM034027D}

(20) Sheldrick, G. M. SHELXTL-97, Program for crystal structure refinement; University of Göttingen: Germany, 1997.

(21) Flack, H. D. Acta Crystallogr. 1983, A39, 876. 